\title{
An environmental impact on the condition of an unfinished building in the OWT technology
}

\author{
Michat Baszen ${ }^{1, *}$ and Czesław Miedziałowski ${ }^{1}$ \\ ${ }^{1}$ Bialystok University of Technology, Department of Geology and Structural Engineering, 15-351 \\ Bialystok, Wiejska str 45E, Poland
}

\begin{abstract}
The aim of the paper is to present the state of the building erected in the OWT technology. The construction of the building has not been completed due to the financial problems of the late 90's of the XX century. As a result of the long-term environmental impact, the object was degraded due to the lack of a flat roof and windows. The impact of precipitation, wind and biological corrosion led to significant degradation and deterioration of structural elements and joints. The paper will present examples of damage caused by environmental impacts. Examples of damage of wall and floor elements as well the deeply corroded steel plate joints will be presented. Highly grown lichens, mosses or mold will be also presented as the examples of biological interactions onto the surface of constructional elements. Structural elements have been tested in a nondestructive manner using sclerometer tests. The results will be described and the conclusions will be presented. The analyzed object presents in an interesting manner that environmental influences could destructively affect the construction of precast RC structural elements, which constitute a significant percentage of the Polish construction market.
\end{abstract}

\section{Introduction}

World War II led to major damage of housing resources in most cities in Poland. Cities such as Warsaw, Wroclaw or Gdynia, but also the center of Bialystok, Gdansk and many other smaller town have been destroyed by more than $80 \%$. The change of the political system in Poland resulted in rapid migrations within the country and from the East. Another reason for migration was overpopulated villages. People had been looking for better living condition and moved to cities where the industry developed. This led to an increase in the percentage of urban population from $37 \%$ to $56 \%$ between 1950 and 1975 [1].

The increase in the number of inhabitants of Polish cities forced finding a solution that allowed a large number of flats to be built quickly. The Large Panel System (LPS) was the answer. Due to its repetitiveness, but also moderate cost of building erection, the LPS construction soon became the leading branch of the housing market.

The popularity of large-panel housing, despite some of it disadvantages, led to the situation the more than $60 \%$ of dwellings in Poland in the 1990's were located in buildings

* Corresponding author: m.baszen@pb.edu.pl 
made of precast concrete slabs [2]. After the change of the political system in Poland, the government was open to new technologies which allowed for greater diversification of housing construction systems. However, it did not mean a total rejection of large-panel housing. The new systems were developed with the elimination of most of the disadvantages of previously used LPS technology [3].

\section{History of Large Panel Systems}

When the first buildings made of precast concrete slab were built in Poland in the 1950's, the Large Panel System was not a brand new technology. It was used successfully in Western Europe for several decades. The first buildings were erected after World War I in Holland. France and Germany were the next countries where that technology was implemented.

In Germany between 1926 and 1930, the estate currently referred to as SplanemannSiedlung was built in Berlin's Lichtenberg district [4], inspired by the Dutch Betondorp in Watergraafsmeer, a suburb of Amsterdam. Another example of using the LPS was Cité de la Muette in Drancy, France (built between 1931 and 1935). Also in Sweden and Finland, these types of residential building were erected using precast concrete slabs.

After World War II a significant number of residential buildings made of precast elements were constructed in Eastern European countries. A wide number of these systems were also provided in the German Democratic Republic. The most popular system was WBS-70 [5]. Almost 42\% of more than 1.5 million flats of LPS buildings were made in the WBS-70 system. Other widely used systems were P2, M10 or PH16.

Since the 1960's the countries of Western Europe began the move away from the LPS. It was particularly related to comfort of use, but also because of safety, which was connected with the failures of its construction [6].

The Jelonki estate in Warsaw was the first place in Poland where the buildings made of precast concrete slabs were erected. Dwelling facilities which were designed in the PBU system allowed the development of buildings up to 11 storeys [7]. The following years brought the development of LPS buildings. The new systems appeared both countrywide as well as only locally.

The systems of large-panel buildings could be divided into two types: closed and open. The closed systems made it possible to erect a facility only in one manner of assembling the precast elements. The typification was limited to a repeatable solution of the type of building, its segments or even just the single dwelling. In open systems there was the possibility of the creation of various configuration of the building.

The closed systems included among others: PBU, Dąbrowa, Domino, Fadom, WUF-T, OWT, WWP, Rataje, Winogrady, and Szczeciński. These systems were usually used locally, although some of them eg. OWT were erected all over the country [8]. The W-70 system as well its modification Wk-70 were the open systems [7,9].

Buildings constructed using LPS technology allowed in most cases to erect up to 11 storeys, while the Winogrady system could manage up to 13 storeys, and the Rataje system could even go up to 16 [9].

\section{Inspected building}

\subsection{Technical state of the building}

The analyzed building was realized in 1989 as the dwelling facility for the employees of a planned dairy in one village near to Bialystok [10]. In and around the city, communal and residential buildings in various types of OWT systems were realized. The variation of the systems used were OWT-67, OWT-67N and OWT-75. 
The discussed building was developed in the OWT-67N system in the staircase configuration, with 5-storeys and 3-stairways with a basement. The assembling works were realized from January to December of 1989. In the end of the year, after the walls of the last storey had been embedded but before flat roof had been laid, the work team left the construction site. The inability to complete the construction was caused by financial problems related to the economical system transformation in Poland.

From the moment of stopping assembling works the analyzed building remained unused without the roof covering, window and door carpentry. The current state of the building is shown in Figure 1.
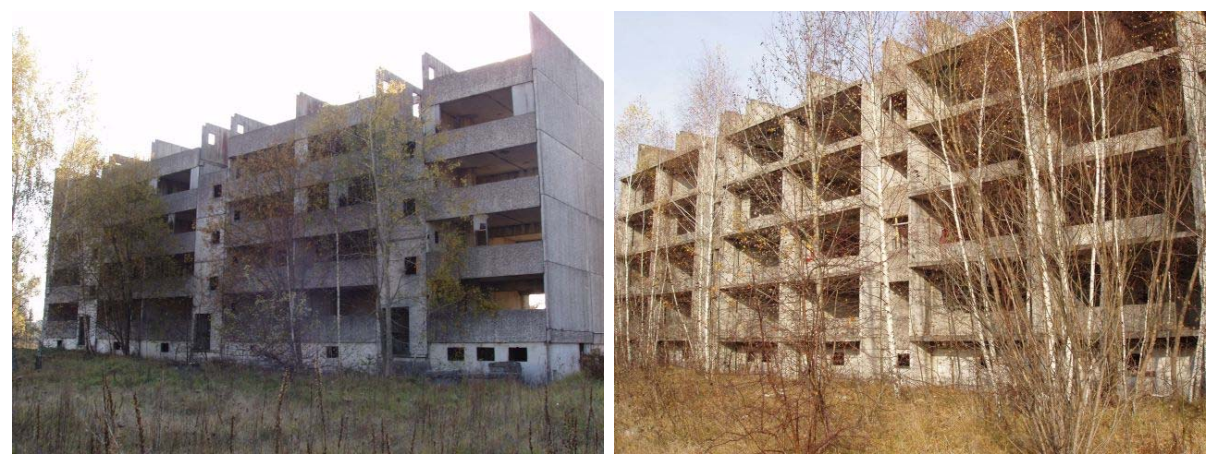

Fig. 1. Analyzed OWT building: front view (left); rear view (right).

\subsection{Environmental influences}

Long-term environmental impacts on the building structure caused significant damage of the construction elements [11]. Precipitation caused the accumulation of water on the surface of the floor element of the last storey. It caused the infiltration of moisture into the concrete and contributed to the corrosion of the surface layer but also to the destruction of concrete on the entire thickness of floor slab, which is shown in Figure 2. These phenomena were intensified by the temperature change from positive to negative values.
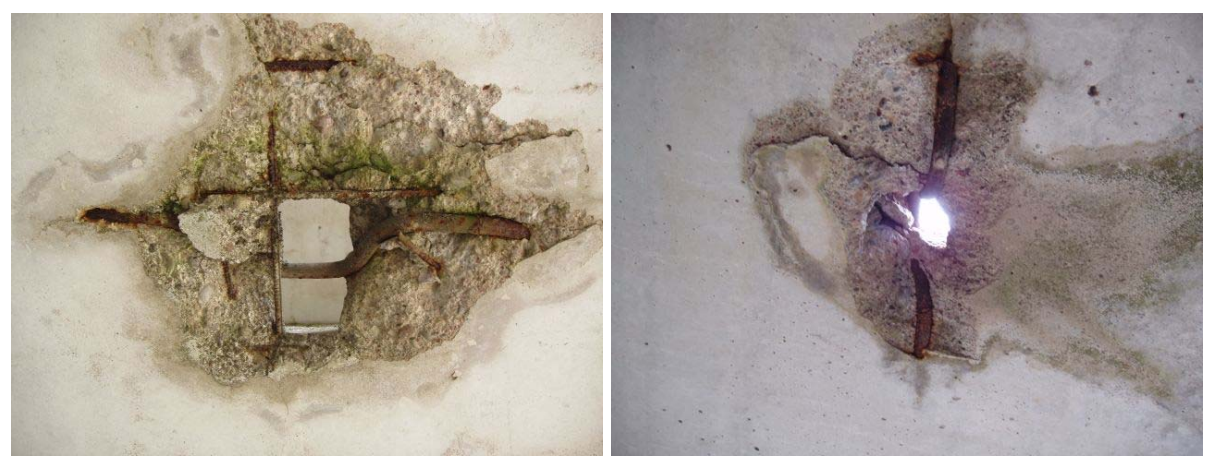

Fig. 2. Degradation of concrete in floor elements.

Atmospheric interactions affected not only the structural elements embedded into last storey. Concrete degradation appeared also on wall and floor elements of lower storeys. The influence of moisture and temperature changes led to the destruction of the concrete cover, exposure of the reinforcement and finally to corrosion of steel bars, as shown in Figure 3. 

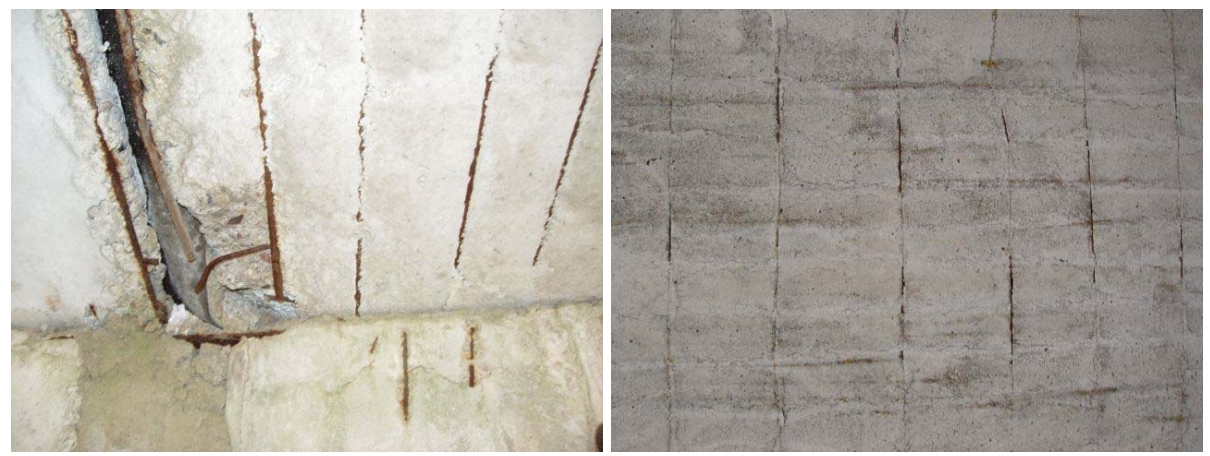

Fig. 3. Corrosion of reinforcement steel in floor element (left) and wall element (right).

The building was erected in an area with no other facilities of similar height in close range. On one side, there are ruins of a single-storey building of a former industrial plant, while on the other side, a few years ago, industrial halls of a lower height were erected. That urban layout allows for free access of wind and rainfall to all storeys except the basement.

Moisture caused by rainfall and high temperatures in the summer meant that it was possible for various types of lichens and mosses on structural elements to grow, shown in Figure 4. In addition, traces of mold are noticeable in shaded areas like the corners of transverse and external walls, shown in Figure 5.
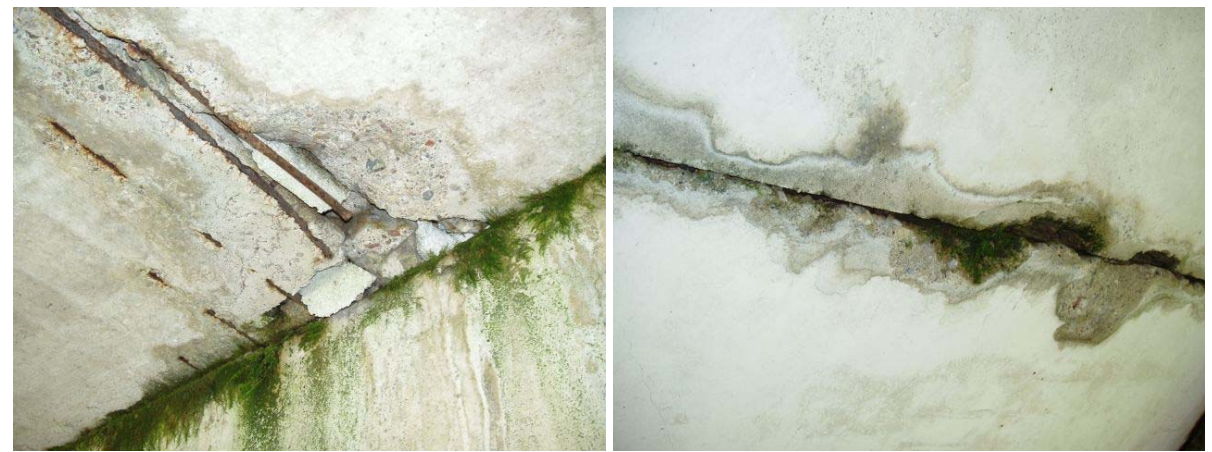

Fig. 4. Lichen and moss on contact area between: wall and floor (left); two floor elements (right).
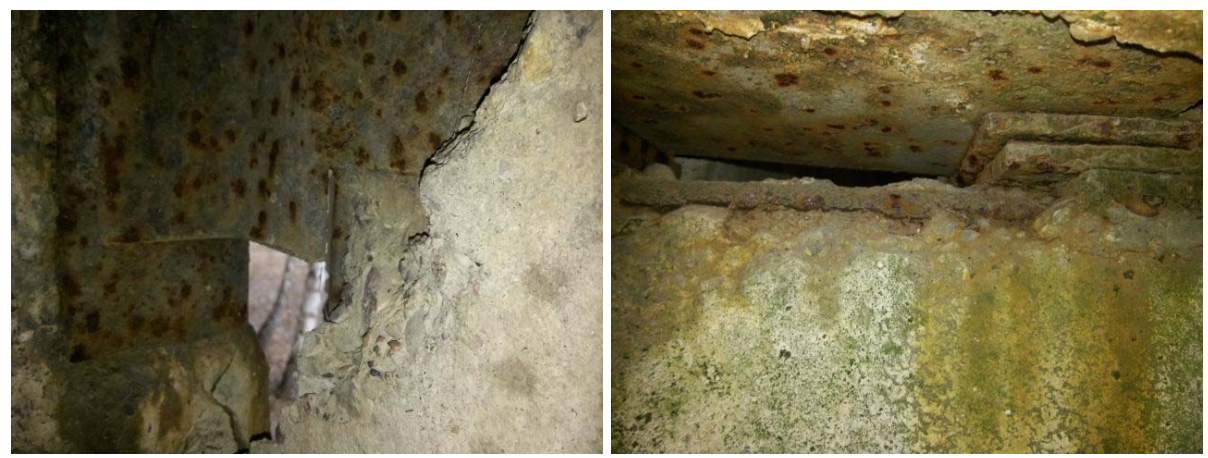

Fig. 5. Mold on joint (left) and structural elements (right). 


\subsection{Quality of elements and joints}

The degradation of structural elements is a result not only of the atmospheric or biological impacts but is connected with the quality of wall and floor slabs. Independent of environmental influences, the manner of joint realization affected its current state.

Precast slabs were made in an in-situ manufacturing factory that affects the quality of the structural elements. The low level of technical knowledge of the workers, the possible lack of supervision, and the problem of material supply caused the manner of the slabs' incorporation into the construction - and the realization of the connection didn't comply with the designed requirements. The quality of workmanship of the joints is shown in Figure 6.
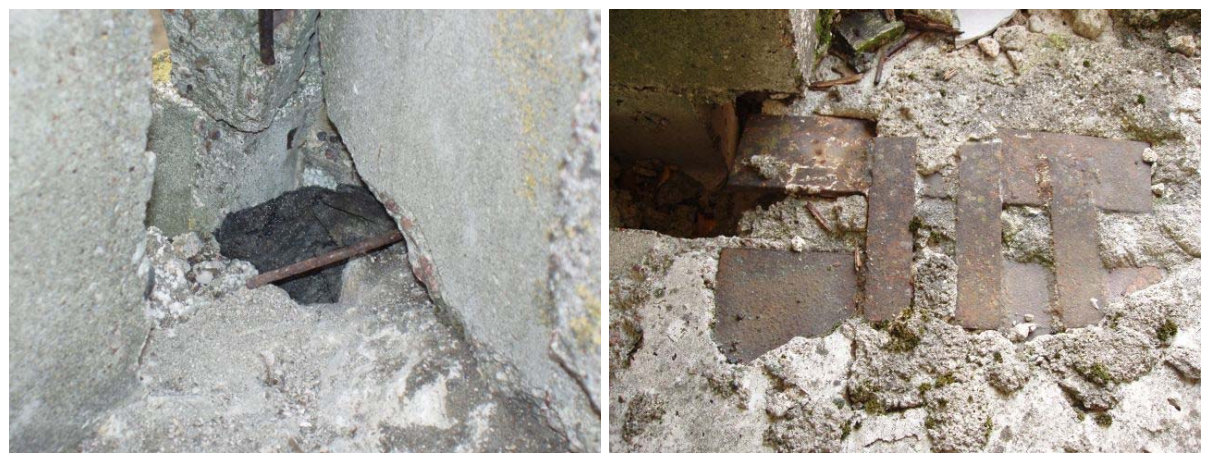

Fig. 6. Connection: floor-to-external and transverse walls (left); floor-to-floor (right).

Difference in dimensions of the structural elements and lack of proper rectification disturbed the positioning of the incorporated elements. The top surface of the longitudinal and transverse walls were on different heights. It led to the need to bend the flat bars to make a connection with the steel hooks in the top surface of wall, shown in Figure 7 (right). Additionally the various types of flat bars were used and the lengths of the welded connections were shorter than necessary. In the case of the connection of transverse and external walls, the additional flat bars were used to provide the horizontal orientation of the external element of the construction, shown in Figure 7 (left).
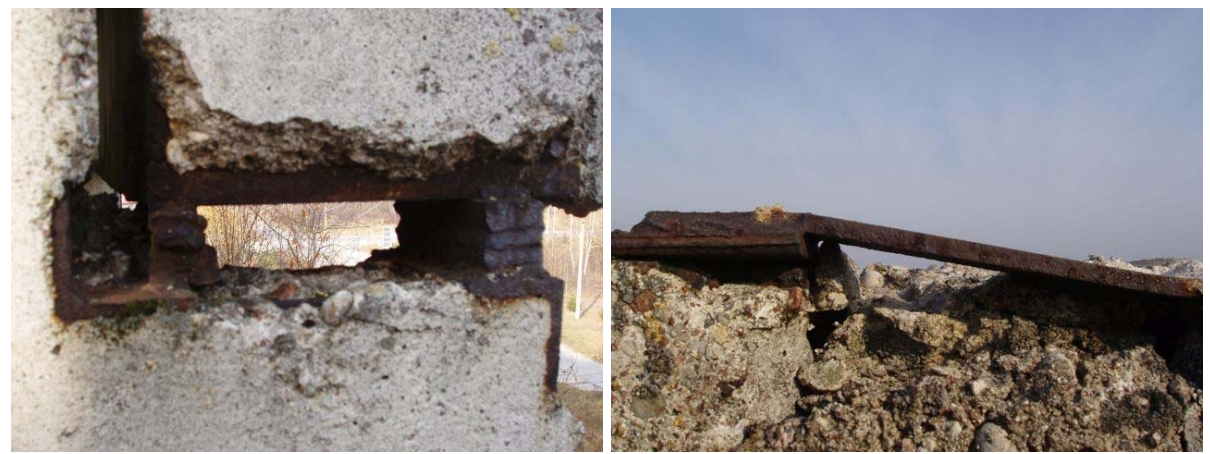

Fig. 7. View of joints: external-to-transverse wall (left); transverse-to-longitudinal wall (right).

The above presented implementation errors caused the joint to be made incorrectly contrary to the system requirements. Empty spaces appearing between connected structural elements were filled by dry-mortar and additional materials achieved on the site. That situation led to free access of moisture to the interior of the junction and caused the 
corrosion of steel elements. Other effects of improper joint construction were the rising of mortar and crumbling of the concrete which finally weakened the load capacity of the joint.

As with any other system, besides the advantages, the OWT technology also had disadvantages. One of them was the method of construction of the façade layer in external wall elements and connection of the cladding with the load bearing part of the external wall. Hooks, anchoring the façade layer with the load bearing layer of wall, were destroyed due to an increase of the stress in the steel [12] as well as the access of the moisture. Similar situation occurred in the case of reinforcement of the façade layer in form of a grid of the steel rods. Due to the lack of concrete cover the reinforcements were often located directly at the layer of insulation, as presented in Figure 8.
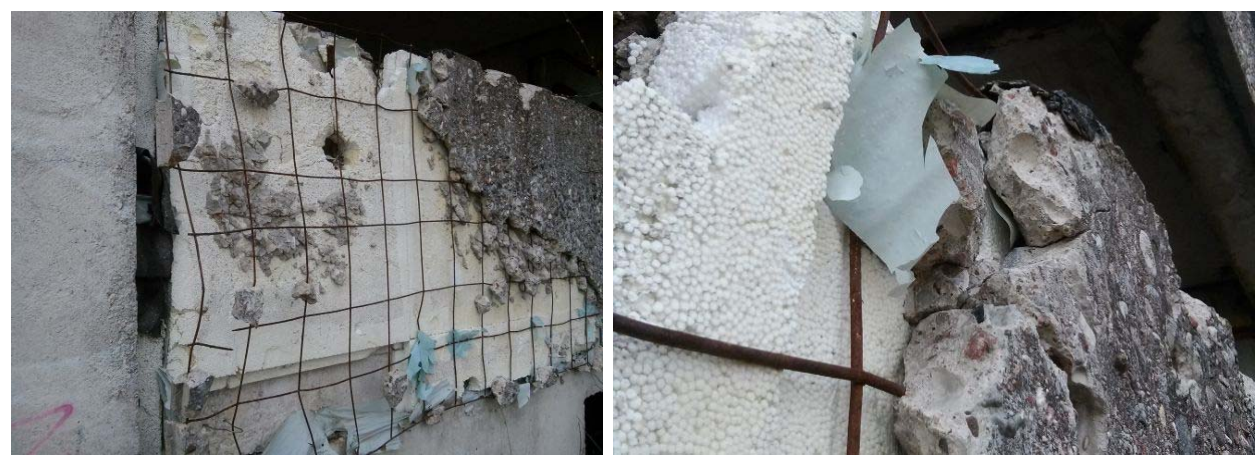

Fig. 8. Degradation of façade cladding in external wall.

\subsection{Sclerometer tests}

Non-destructive sclerometer tests were conducted for three different walls and three different floor slabs on three different storeys. The measurements was conducted in six points for nine recoils at each point. The calculations of the concrete strength were provided according to the instruction ITB-210 [13] referring to the Polish Standard [14]. The application of the Polish Standard instead of the European Standard was motivated by the fact that the analyzed building was designed and erected according to the normative standard required in the 1980's.

Tables 1-3 present guaranteed strength of concrete as well the class of concrete in floor elements over first, third and fourth storeys. The guaranteed strength corresponds with actually used characteristic strength of concrete. Tables 4-6 present guaranteed strength of concrete as well the class of concrete in wall elements of the second, fourth and fifth storeys. All tables also contain values of relative and standard deviations - the factors necessary to define the quality of the concrete.

The tests carried out show that the concrete in floor slabs were not of the highest quality. Class of concrete varies from B 12.5 to B 25 with large relative and standard deviations. The relative deviation should not exceed 12\% [15]. As seen in the tables above, only twice this condition was reached. It indicates a significant heterogeneity of concrete caused by the technological errors, inaccuracy of production in the in-situ manufacturing factories as well the impact of environmental factors.

In contrast to the floor slabs, quality of the concrete of wall elements is acceptable. Class of concrete varies from B12.5 to B30, in most cases they met the requirements of B25 class. Relative deviation, except one case, did not exceed the limit of $12 \%$. It shows the atmospheric factors less affected the degradation of concrete in wall elements in relation to floor slabs. 
Table 1. Calculated strength and class of concrete in floor element over fourth storey.

\begin{tabular}{|c|c|c|c|c|c|}
\hline No & $\begin{array}{c}\text { Relative } \\
\text { deviation }\end{array}$ & $\begin{array}{c}\text { Guaranteed } \\
\text { strength }\end{array}$ & $\begin{array}{c}\text { Standard } \\
\text { deviation }\end{array}$ & $\begin{array}{c}\text { Class } \\
\text { of concrete }\end{array}$ & $\begin{array}{c}\text { Quality } \\
\text { of concrete }\end{array}$ \\
\hline & $v_{\mathrm{R}}[\%]$ & $\mathrm{R}_{\mathrm{bG}}[\mathrm{MPa}]$ & $v_{\mathrm{R}}[\mathrm{MPa}]$ & {$[-]$} & {$[-]$} \\
\hline 1 & 9.49 & 20.40 & 2.29 & $\mathrm{~B} 20$ & very good \\
\hline 2 & 18.89 & 14.00 & 3.84 & $\mathrm{~B} 12.5$ & sufficient \\
\hline 3 & 10.84 & 19.00 & 2.51 & $\mathrm{~B} 17.5$ & good \\
\hline
\end{tabular}

Table 2. Calculated strength and class of concrete in floor element of third storey.

\begin{tabular}{|c|c|c|c|c|c|}
\hline No & $\begin{array}{c}\text { Relative } \\
\text { deviation }\end{array}$ & $\begin{array}{c}\text { Guaranteed } \\
\text { strength }\end{array}$ & $\begin{array}{c}\text { Standard } \\
\text { deviation }\end{array}$ & $\begin{array}{c}\text { Class } \\
\text { of concrete }\end{array}$ & $\begin{array}{c}\text { Quality } \\
\text { of concrete }\end{array}$ \\
\hline & $v_{\mathrm{R}}[\%]$ & $\mathrm{R}_{\mathrm{bG}}[\mathrm{MPa}]$ & $v_{\mathrm{R}}[\mathrm{MPa}]$ & {$[-]$} & {$[-]$} \\
\hline 1 & 15.55 & 27.10 & 5.65 & $\mathrm{~B} 25$ & average \\
\hline 2 & 16.55 & 22.00 & 5.00 & $\mathrm{~B} 20$ & sufficent \\
\hline 3 & 13.52 & 25.20 & 4.37 & $\mathrm{~B} 25$ & average \\
\hline
\end{tabular}

Table 3. Calculated strength and class of concrete in floor element of first storey.

\begin{tabular}{|c|c|c|c|c|c|}
\hline No & $\begin{array}{c}\text { Relative } \\
\text { deviation }\end{array}$ & $\begin{array}{c}\text { Guaranteed } \\
\text { strength }\end{array}$ & $\begin{array}{c}\text { Standard } \\
\text { deviation }\end{array}$ & $\begin{array}{c}\text { Class } \\
\text { of concrete }\end{array}$ & $\begin{array}{c}\text { Quality } \\
\text { of concrete }\end{array}$ \\
\hline & $v_{\mathrm{R}}[\%]$ & $\mathrm{R}_{\mathrm{bG}}[\mathrm{MPa}]$ & $v_{\mathrm{R}}[\mathrm{MPa}]$ & {$[-]$} & {$[-]$} \\
\hline 1 & 22.10 & 19.50 & 6.75 & $\mathrm{~B} 17.5$ & bad \\
\hline 2 & 15.29 & 21.00 & 4.28 & $\mathrm{~B} 20$ & average \\
\hline 3 & 13.05 & 24.3 & 4.04 & $\mathrm{~B} 20$ & good \\
\hline
\end{tabular}

Table 4. Calculated strength and class of concrete in wall element of fifth storey.

\begin{tabular}{|c|c|c|c|c|c|}
\hline No & $\begin{array}{c}\text { Relative } \\
\text { deviation }\end{array}$ & $\begin{array}{c}\text { Guaranteed } \\
\text { strength }\end{array}$ & $\begin{array}{c}\text { Standard } \\
\text { deviation }\end{array}$ & $\begin{array}{c}\text { Class } \\
\text { of concrete }\end{array}$ & $\begin{array}{c}\text { Quality } \\
\text { of concrete }\end{array}$ \\
\hline & $v_{\mathrm{R}}[\%]$ & $\mathrm{R}_{\mathrm{bG}}[\mathrm{MPa}]$ & $v_{\mathrm{R}}[\mathrm{MPa}]$ & {$[-]$} & {$[-]$} \\
\hline 1 & 9.19 & 29.40 & 3.18 & $\mathrm{~B} 25$ & very good \\
\hline 2 & 11.24 & 14.90 & 2.06 & $\mathrm{~B} 12.5$ & good \\
\hline 3 & 12.76 & 27.5 & 4.44 & $\mathrm{~B} 25$ & very good \\
\hline
\end{tabular}

Table 5. Calculated strength and class of concrete in wall element of fourth storey.

\begin{tabular}{|c|c|c|c|c|c|}
\hline No & $\begin{array}{c}\text { Relative } \\
\text { deviation }\end{array}$ & $\begin{array}{c}\text { Guaranteed } \\
\text { strength }\end{array}$ & $\begin{array}{c}\text { Standard } \\
\text { deviation }\end{array}$ & $\begin{array}{c}\text { Class } \\
\text { of concrete }\end{array}$ & $\begin{array}{c}\text { Quality } \\
\text { of concrete }\end{array}$ \\
\hline & $v_{\mathrm{R}}[\%]$ & $\mathrm{R}_{\mathrm{bG}}[\mathrm{MPa}]$ & $v_{\mathrm{R}}[\mathrm{MPa}]$ & {$[-]$} & {$[-]$} \\
\hline 1 & 8.27 & 28.3 & 2.71 & $\mathrm{~B} 25$ & very good \\
\hline 2 & 9.46 & 20.50 & 2.30 & $\mathrm{~B} 20$ & very good \\
\hline 3 & 13.20 & 28.30 & 4.77 & $\mathrm{~B} 25$ & good \\
\hline
\end{tabular}

Table 6. Calculated strength and class of concrete in wall element of second storey.

\begin{tabular}{|c|c|c|c|c|c|}
\hline No & $\begin{array}{c}\text { Relative } \\
\text { deviation }\end{array}$ & $\begin{array}{c}\text { Guaranteed } \\
\text { strength }\end{array}$ & $\begin{array}{c}\text { Standard } \\
\text { deviation }\end{array}$ & $\begin{array}{c}\text { Class } \\
\text { of concrete }\end{array}$ & $\begin{array}{c}\text { Quality } \\
\text { of concrete }\end{array}$ \\
\hline & $v_{\mathrm{R}}[\%]$ & $\mathrm{R}_{\mathrm{bG}}[\mathrm{MPa}]$ & $v_{\mathrm{R}}[\mathrm{MPa}]$ & {$[-]$} & {$[-]$} \\
\hline 1 & 8.40 & 22.70 & 2.21 & $\mathrm{~B} 20$ & very good \\
\hline 2 & 10.64 & 24.70 & 3.18 & $\mathrm{~B} 20$ & good \\
\hline 3 & 8.10 & 34.20 & 3.20 & $\mathrm{~B} 30$ & good \\
\hline
\end{tabular}




\section{Conclusions}

The conducted review and analysis of the building structure developed in OWT technology reveal a significant influence of environmental impacts on the condition of the structure. Rainwater and moisture allow the growth of lichens, mosses and fungi (mold). The elements which were soaked in water and had limited access to the wind, like a junction between two floor slabs or a floor-to-wall connection, were especially exposed to bio-degradation.

Incorrectly produced wall and floor elements and poorly protected joints were destroyed and corroded. In concrete slabs with a thin cover layer, the surrounding concrete was destroyed and reinforcement bars were revealed. Steel exposed to atmospheric impacts started to corrode. These effects were increased by the significant temperature fluctuations.

Joints were developed in a different manner than the catalog requirements. Inadequate flat bars were used and connected with the steel hooks of walls and floors by weld with inadequate length [3]. Lack of proper rectification during incorporation of the elements led to assembly errors corrected by additional or bent flat bars to provide proper orientation of the walls.

Non-destructive sclerometer tests showed the quality of the structural concrete differed for various elements. The results obtained from the tests presented significant spread of guaranteed strength. Additionally, in the case of floor slabs, relative deviation exceeded the recommended $12 \%$ and testified to the low quality of the structural elements.

The conducted analyses show great importance of protection against moisture and accuracy of joint construction in Large Panel System buildings. Degradation of concrete, corrosion of reinforcement steel or steel connectors in the joints involve the danger of disaster in the building. Due to the very large number of buildings erected of large panel elements in Poland, this is a particularly important problem and worth further analysis.

Paper was realized as part of the BUT project No S/WBiIS/1/18 and was financed by MNiSW of Poland.

\section{References}

1. K. Lewandowska-Gwarda, E. Antczak, Roczniki. Kolegium Analiz Ekonomicznych 39, 8 (in Polish, 2015)

2. A. Rybka, COST Action C12, Lisbon, 19 and 20 April, 207-216, (2003)

3. J. Makuszewski, Mater. Bud. 459 (11/2010), 4 (in Polish, 2010)

4. A. Lange, Berlin in der Weimarer Republik, (in German Berlin 1987)

5. R. DiGiulio, Z. Bozinovski, L.G.W. Verhoef, (Improving the quality of existing building envelopes: structures, Research in Architectural Engineering Series, IOS Press, Amsterdam, 2007)

6. C. Pearson, N. Delatte, J. Perform. Constr. Fac. ASCE, 19(2), 172-177 (2005)

7. Podręcznik typologii budynków mieszkalnych z przykładami działań mających na celu zmniejszenie ich energochtonności. W ramach projektu Tabula. (in Polish, Narodowa Agencja Poszanowania Energii SA, Warszawa 2011)

8. Z. Dzierżewicz, W. Starosolski, (Systemy budownictwa wielkoptytowego $w$ Polsce w latach 1970-1985, in Polish, Wolters Kluwer Polska, Warsaw, 2010)

9. M. Kłopotowski, Arch. et Art. 2/2009, 31-38 (in Polish 2009)

10. C. Miedziałowski, M. Baszeń, Appl. Mech. Material., 878, 219-223 (2018) 
11. C. Miedziałowski, M. Baszeń, M. Kosior-Kazberuk, A. Żakowicz, T. Chyży, D. Siwik, JCEEA, 33 (63, 1-t.1), 27-34 (in Polish 2016)

12. P. Knyziak, J.Krentowski, P.Bieranowski, MATEC Web of Conf. 117, 00080 (2017)

13. Instrukcja ITB 210, Instrukcja stosowania młotków Schmidta do nieniszczacej kontroli jakości betonu (in Polish, 1977)

14. PN-74/B-06262, Nieniszczace badania konstrukcji z betonu. Metoda sklerometryczna badania wytrzymałości betonu na ściskanie za pomoca młotka Schmidta typu N (Polish Standard, 1974)

15. D. Domańska, Górnictwo i Geotechnika, 33 (3-1), 131-141 (in Polish 2009) 